\title{
TEOG ve LGS Sistemlerinin Öğrenci, Öğretmen, Veli ve Öğretmen Velilerin Görüşleri Açısından İncelenmesi
}

\author{
Yasemin Kuzu \\ Kırşehir Ahi Evran Üniversitesi, Eğitim Fakültesi, Eğitim Bilimleri Bölümü, Kırşehir \\ yaseminkuzu@yandex.com \\ ORCID ID: 0000-0003-4301-2645
}

Okan Kuzu

Kırşehir Ahi Evran Üniversitesi, Eğitim Fakültesi, Matematik ve Fen Bilimleri Eğitimi Bölümü, Kırşehir okan.kuzu@ahievran.edu.tr

ORCID ID: 0000-0003-2466-4701

Selahattin Gelbal

Hacettepe Üniversitesi, Eğitim Fakültesi, Eğitim Bilimleri Bölümü, Ankara

sgelbal@gmail.com

ORCID ID: 0000-0001-5181-7262

\begin{tabular}{|c|c|c|c|}
\hline \multicolumn{4}{|c|}{ Araştırma Makalesi } \\
\hline Geliş Tarihi: $\quad 29.04 .2019$ & Revize Tarihi: & Kabul Tarihi: & 12.06 .2019 \\
\hline
\end{tabular}

\section{Attf Bilgisi}

Kuzu, Y., Kuzu, O ve Gelbal, S. (2019). TEOG ve LGS sistemlerinin öğrenci, öğretmen, veli ve öğretmen velilerin görüşleri açısından incelenmesi, Ahi Evran Üniversitesi Sosyal Bilimler Enstitüsü Dergisi, 5(1), 112130 .

\section{ÖZ}

Bu çalışmada, "Temel Eğitimden Ortaöğretime Geçiş" ve "Liselere Giriş Sınavı” sistemlerinin en çok kabul ve ret gören özellikleri öğrencilerin, öğretmenlerin, velilerin ve öğretmen velilerin görüşleri doğrultusunda incelenmiştir. Liselere Giriş Sınavı sistemi Temel Eğitimden Ortaöğretime Geçiş sistemi ile karşılaştırılmış, olumlu ve olumsuz yanları belirlenmiştir. Nicel ve nitel araştırma yaklaşımlarının birlikte kullanıldığı bu çalışmada, nicel araştırma yaklaşımlarından tarama modeli, nitel araştırma yaklaşımlarından ise durum çalışması modeli kullanılmıştır. Nicel veriler betimsel istatistiklerden yararlanılarak analiz edilmiş ve betimleme sürecinde, Temel Eğitimden Ortaöğretime Geçiş ve Liselere Giriş Sınavı sistemi ile ilgili literatür taranarak 25 maddelik bir anket hazırlanmıştır. Anket, toplam 415 kişiye uygulanmış ve elde edilen sonuçlara göre, Fen Lisesi gibi özel nitelik gerektiren okullara sınavla öğrenci alımının daha doğru bir karar olduğu belirtilmiştir. Adrese en yakın okula kayıt yaptırmanın ve sınavın tek bir oturumda tamamlanmasının ise yanlış olduğu vurgulanmıştır. Nitel veriler ise içerik analizi ile çözümlenmiş ve "Sınav Koordinatörlüğü", "Sınav Sayısı", "Soru Dağılımı", "Soru Tipi” ve "Yerleştirme Tipi” kategorileri altında temalar oluşturulduğu görülmüştür. Liselere Giriş Sınavı'nın olumsuz yanlarının daha fazla olduğu belirlenmiş ve Temel Eğitimden Ortaöğretime Geçiş sistemi daha tercih edilebilir bir sistem olarak görülmüştür. Bu yönüyle çalışmanın ortaöğretime geçiş sınav sistemlerinin hazırlanma sürecine katkı sağlayacağı düşünülmektedir.

Anahtar Kelimeler: Temel eğitimden ortaöğretime geçiş, liselere giriş sınavı, sınav sistemi

\section{Investigation of TEOG and LGS Systems in terms of Students', Teachers', Parents' and Teacher Parents' Opinions}

\begin{abstract}
In this study, the most accepted and rejected features of "Transition from Basic Education to Secondary Education" and "High School Entrance Exam" systems were examined according to the opinions of students, teachers, parents and also parents who are teachers at the same time. High School Entrance Exam system was compared with Transition from Basic Education to Secondary Education system and its positive and negative aspects were determined. In this study in which quantitative and qualitative research approaches are used, descriptive and case study models are used. The data were analyzed by using content analysis and descriptive statistics. In the descriptive process, a 25-item questionnaire was prepared by reviewing the literature about Transition from Basic Education to Secondary Education and High School Entrance Exam systems. The questionnaire was administered to 415 individuals and as the results, it was stated that placement by doing a test to schools that require special qualification such as Science High School was to be a more accurate decision. It was emphasized that it was wrong to register to the nearest school and complete the exam in one session. Qualitative data were analyzed by content analysis and it was seen that themes were formed under
\end{abstract}


the categories of "Exam Coordinatorship“, "Number of Exam“, "Question Distribution“, "Question Type" and "Placement Type". Moreover, compared to Transition from Basic Education to Secondary Education system, this system was found to be weaker and Transition from Basic Education to Secondary Education system was considered a more preferable system. Thanks to the study, it was thought that contribution to the preparation of secondary education exam systems will be contributed.

Keywords: Transition from basic education to secondary education, high school entrance exam, examination system

\section{Giriş}

Bireyin sosyal yeterliliğine ve bireysel gelişimine yardımcı olan eğitim, yetenek ve davranış biçimlerini geliştiren süreçlerin toplamıdır (Srinivasan ve Ambedkar, 2015). Bu sebeple, her ülkenin kendi eğitim politikası vardır ve bu politika toplumun ihtiyaçlarının karşılanması, bireye sunulan hizmetlerin niteliğinin artması, öğrenci, öğretmen ve veli arasındaki ilişkilerin güçlenmesi amacıyla eğitim sisteminde bazı yenilikler yapılmasını uygun görmektedir. Türk eğitim sisteminin temel amacı; insan haklarına saygılı ve topluma karşı sorumluluk duyan nitelikli bireyler yetiştirmek ve öğretmen, öğrenci, veli işbirliği içerisinde eğitim-öğretim sürecinin etkili bir şekilde geçirilmesini sağlamak şeklinde tanımlanmıştır (MEB, 1973). Okul öncesi ile başlayan ve lisansüstü eğitimi de içine alan bu süreç, öğrencilerin bir alt kademeden bir üst kademeye geçmesi ile devam etmektedir. Kaliteli bir yaşama ve kariyere sahip olmak isteyen öğrenciler için eğitim-öğretimin her kademesinde etkili bir öğrenme ortamının oluşmasının gerektiği düşünülmektedir. Öğrenciler bu süreçte iyi bir eğitim almak istemekte, ilgi, yetenek ve imkânları doğrultusunda tercihlerini yapmaktadır. Kendilerini iş hayatına ve yükseköğretime hazırlayacak olan ortaöğretim kurumlarını tercih etme süreci ise öğrenciler için eğitim-öğretim içerisinde önemli bir yere sahiptir.

Eğitim sisteminin her kademesinde olduğu gibi ortaöğretim kurumlarına öğrenci seçimi yapılırken de büyük bir titizlik gösterilmelidir. Öğrencilerin ilgi ve yeteneklerini tanıma ve bu doğrultuda onları yönlendirme, öğrencilerin mesleki yönden daha istekli ve başarılı olmasına imkân tanıyacaktır. Bu bağlamda, öğrencilerin ortaöğretim kurumlarına geçiş aşamasında ülkelere göre farklı uygulamalar yapılmaktadır. Sınava dayalı uygulamaların yanında, mezuniyet notu, öğretmen görüşleri ve etkili rehberlik faaliyetleri gibi uygulamalar olduğu gibi sınavsız geçiş uygulamaları ile de öğrenciler seçilmektedir (Aykaç ve Atar, 2014).

Türk eğitim sisteminde, ortaöğretim kurumlarına geçiş, sınava dayalı olarak yapılmakta ve geçmişi 1955 yıllarına dayanmaktadır. Bu dönemde, ortaokul son sınıf öğrencilerine Devlet Ortaokul İmtihanı uygulanmaya başlanmış ve öğrenciler bu sınavda gösterdikleri başarı ile bir üst kademeye geçme hakkı kazanmışlardır (Küçüker, 2017). Ayrıca, 1955 yılında ilk olarak "Maarif Koleji” adıyla açılan ve yabancı dilde eğitim veren kolejler, öğrencilerini yaptıkları sınavlara göre ilkokuldan (5.sinıf) itibaren kabul etmiştir (Güven, 2010; Özkan, 2017). Ortaokul ve lise kısımlarını bir arada bulunduran bu kolejler 1975 yılında Anadolu Liseleri olarak adlandırılmış (MEB, 1975) ve 1999 yılında başlayan sekiz yıllık zorunlu eğitim uygulamasıyla birlikte öğrencilerini ortaokul son sınıftan (sekizinci sınıf) itibaren seçmeye başlamıştır. 1964 yılında faaliyete geçen Fen Liseleri de sınavla öğrenci alan diğer bir ortaöğretim kurumu olmuştur (Gür, Çelik ve Çoşkun, 2013; Özkan, 2017). Ayrıca, ilk olarak 1985 yılında açılan ve sadece ilk yılında ön kayıt sistemiyle öğrenci alan Anadolu İmam Hatip Liseleri sınavla öğrenci alan ortaöğretim kurumlarındandır (Özkan, 2017). Geçmişi, 1848 yılında İstanbul'da açılan Darülmuallim (Erkek öğretmen okulu) adlı okula dayanan öğretmen okulları ise 1990 yılından itibaren Anadolu Öğretmen Lisesi olarak adlandırılmış ve öğrencilerini sınavla kabul etmeye başlamıştır (MEB, 1990). 2014 yılında yapılan değişiklikle birlikte Anadolu Öğretmen Liseleri yerini Fen, Anadolu ve 2003 yılında faaliyete geçen ve öğrencilerini sınavla alan diğer bir ortaöğretim kurumu olan Sosyal Bilimler Liselerine bırakmıştır (MEB, 2014).

Türk eğitim sisteminde, 1997-1998 eğitim öğretim yılında ilk defa uygulanmaya başlanan ve Liselere Giriş Sınavı (LGS) olarak adlandırılan merkezi bir sınavla öğrenciler ortaöğretim kurumlarına yerleştirilmeye başlanmıştır. 2004-2005 eğitim öğretim yılında ise LGS yerine Ortaöğretim Kurumları Seçme ve Yerleştirme Sınavı (OKS) uygulanmaya başlanmış ve bu sınav sonuçlarına göre özel 
okullara ve polis kolejlerine de öğrenci seçilmeye başlanmıştır. Ayrıca bu sınavın içerisine devlet parasız yatılı ve bursluluk sınavı da katılmıştır. LGS ve OKS sadece 8. Sınıf öğrencilerine uygulanmasına rağmen 2007-2008 eğitim öğretim yılında uygulanmaya başlanan Seviye Belirleme Sınavı (SBS) ile 8. Sınıfın haricinde 6. ve 7. Sınıf öğrencileri de yılsonunda girdikleri sınavlarla ortaöğretim kurumlarına yerleştirilmişlerdir. 2011-2012 eğitim öğretim yılı itibariyle bu sınav sisteminin 6. ve 7. Siniflardan kademeli olarak kaldırılmasına ve sadece 8. Sinıfin sonunda uygulanmasına karar verilmiştir. 2012-2013 eğitim öğretim yalında ise sadece 8. Sınıflar için SBS uygulanmış ve 2013-2014 eğitim öğretim yılı itibariyle yerini adında sınav kelimesi geçmeyen Temel Eğitimden Ortaöğretime Geçiş (TEOG) sistemine bırakmıştır. TEOG sisteminin genel amaçları doğrultusunda öğretmenin ve okulun rolünün arttırılması, öğrenci, öğretmen ve okul ilişkisinin güçlendirilmesi amaçlanmaktadır. Ayrıca, orta ve uzun vadede ders dışı sosyal, kültürel, sanatsal ve sportif etkinlikler ile değerlendirilmelerin yapılmasına imkân tanınmaktadır (Atılgan, 2017; Kaplan, 2017).

Bu sisteme göre 8. Sınıf öğrencileri 6 temel dersten yılda toplam 12 ortak sınava girmekte ve bu sınavların sonuçları ortaöğretim kurumlarına yerleştirilmede kullanılacak puanların hesaplanmasında $\% 70$ etkili olmaktadır. 6. 7. ve 8. Sınıf yılsonu başarı puanları ise yerleştirme puanlarına \%30 katkı sağlamaktadır. Bu sistemde yeni bir sınav yerine öğrencilerin her ders için zaten girdikleri yazılılardan bir tanesi MEB tarafından merkezi olarak yapılmaktadır. Bu sistemde, öğretmen, öğrenci ve okul arasındaki ilişkiyi güçlendirmek amacıyla tüm sınavlar yerine sadece bir sınavın MEB tarafından yapılması uygun görülmüştür (ERG, 2013).

\section{TEOG sisteminin genel özellikleri (MEB, 2013)}

- 8. Sınıf öğrencileri Matematik, Fen ve Teknoloji, Türkçe, T.C. İnkılap Tarihi ve Atatürkçülük, Yabancı dil, Din Kültürü ve Ahlak Bilgisi şeklindeki 6 temel dersten ortak sınava girecektir.

- Ortak sınavlar her dönem MEB tarafindan merkezi olarak yapılacak ve dönem içerisinde yapılan yazılılardan biri olarak kabul edilecektir.

- İki yazılısı olan derslerden birincisi, üç yazılısı olan derslerden ise ikincisi ortak sınav şeklinde yapilacaktır.

- Ortak sınavlar her dönem iki okul gününe yayılarak yapılacak ve her gün 3 sınava girilecektir. Ayrıca, sinav günlerinde ders yapılmayacaktır.

- Her bir ortak sinavda 4 seçenekli çoktan seçmeli 20 soru sorulacak ve iptal edilen soru yoksa her bir soru 5 puan olarak değerlendirilecektir. Puanların hesaplanmasında düzeltme formülü uygulanmayacaktır.

- Ortak sınavlar orta ve uzun vadede açık uçlu soruları da içerecek hale dönüş̧ürülecektir.

- Öğrenciler ortak sınavlara olağanüstü haller ve özel durumlar dışında kendi okullarında girecektir.

- Sinavlarda görev alacak öğretmenler kendi okullarından farklı bir okulda görevlendirilecektir.

- Geçerli bir mazeret sebebiyle ortak sinava giremeyen öğrenciler için bir mazeret sınav1 yapılacaktır. Mazeret sınavları önceden belirlenen bir hafta sonunda belirli sınav merkezlerinde uygulanacaktır.

Uygulanan TEOG sisteminin sonuç temelli sınavlardan ibaret olduğu ve yapılandırmacı yaklaşımda uygulanan süreç temelli değerlendirme süreci ile örtüşmediği görülmektedir (Aykaç ve Atar, 2014). Bu sebeple, eğitimciler açısından birçok tartışmaya neden olacağı düşünülmektedir. 2017-2018 eğitim öğretim yılı itibariyle TEOG sistemimin kaldırılması gündeme gelmiş ve yerine Veli Tercihine Bağlı Serbest Kayıt Sistemi gelmiştir. Eğitim Bölgesi ve Sınavsız Mahalli Yerleştirme Sistemi olarak açıklanan ve kısaca Liseye Geçiş Sınavı (LGS) olarak adlandırılan bu sistemin temel mantığ1 adrese dayalı yerleştirme ve isteğe bağlı olmasıdır. İlk yıl geçiş sistemi adıyla sadece 8 . Sınıflara uygulanacak ve sınava giren öğrenciler \%70 sınav puanı, \%30 okul başarı puanı ile ortaöğretim kurumlarına yerleştirilecektir. 2018-2019 eğitim-öğretim yılından itibaren ise 6. 7. ve 8 . Sınıfların tamamına uygulanacak ve merkezi sınav yerine İl Milli Eğitim Müdürlükleri tarafından sınavlar düzenlenecektir. Bu sinavlarda sorular hazırlanırken bakanlığın madde havuzundan yararlanılacaktır. Herhangi bir İl Milli Eğitim Müdürlügünün soru havuzundan seçtiği soru otomatik 
olarak havuzdan çıkarılacak ve başka hiçbir eğitim bölgesinde aynı soru sorulmayacaktır (Atılgan, 2017; Y1lmaz, 2017).

\section{LGS sisteminin genel özellikleri}

- 6. 7. ve 8. Sınıf öğrencileri eğitim yılı içerisinde Matematik, Fen ve Teknoloji, Türkçe, T.C. İnkılap Tarihi ve Atatürkçülük, Yabancı dil, Din Kültürü ve Ahlak Bilgisi şeklindeki 6 temel dersten sinavlara girecektir.

- Öğrencilerin 6. ve 7. Sınıf not ortalamalarının yüzde 20'si; 8. Sınıf not ortalamasının ise yüzde 60’1 hesaplanacak ve 8. Sınıf sonunda Fen Liseleri ile bazı proje okulları için tercih yapmaları sağlanacaktır.

- Sayısal ve sözel bölümlerden oluşan sınav farklı iki oturum şeklinde olmamakla birlikte her iki bölüm arasında kısa bir ihtiyaç molası verilecektir.

- Soru dağılımları her ders için aynı olmayacak, Matematik, Fen ve Teknoloji, Türkçe dersleri için 20; T.C. İnk1lap Tarihi ve Atatürkçülük, Yabancı dil, Din Kültürü ve Ahlak Bilgisi dersleri için ise 10 ar soru sorulacaktır.

- Sinav sözel bölüm için 75; sayısal bölüm için ise 80 dakika olup toplam 155 dakika sürecek ve 3 yanlış cevap 1 doğru cevabı götürecektir.

- Test sorularının yanı sıra açık uçlu sorular da sorulacaktır. Cevap anahtarında yanlış, az doğru ve doğru şeklinde seçenekler olacaktır.

- Sinav zorunlu olmayacak, sınavdan alınan puanlar sadece Fen Liseleri ile bazı proje okullarına giriş içi kullanılacaktır.

- Sınava giren öğrenciler en fazla 15 tercih yapabilecektir. Bunların beşini sınavla öğrenci alan okullar; beşini adrese dayalı olarak öğrenci alan okullar ve diğer beşini de pansiyonlu okullar oluşturmaktadır. Sınava girmeyen öğrenciler ise en fazla 10 tercih yapabilecek ve sinavla öğrenci alan okulları yazamayacaktır.

- Pansiyonlu okullarda yatak sayısı kadar kontenjan belirlenecek ve farklı eğitim bölgelerinden tercih yapılacaktır. Mahalli yerleştirmede kayıt önceliği kriterleri öğrencinin tercih sırası, evine yakınlık derecesi ve okula yakınlık derecesi şeklinde belirlenmiştir. Pansiyonlu okulları tercihte ise en uzak öğrenciler daha avantajlı sayılacak, okul başarı puanları ise dikkate alınmayacaktır.

- Tercihlerine yerleşemeyen veya hiç tercih yapmayan öğrenciler için açık lise gibi seçenekler sunulacaktır.

Türk eğitim sisteminde 1955 yıllından itibaren başlayan ortaöğretim kurumlarına geçiş sınavları yıllar içerisinde değişikliklere uğrasa da temelinde sınava dayalı olarak yerleştirmeye öncelik vermiştir. 2017 yllı itibariyle faaliyete geçen LGS sisteminde ise sınava dayalı geçişlerin oranı azaltılmış ve adrese dayalı geçişin önemi arttırılmıştır. Her ne kadar bu sistem içerisinde sinavdan bahsedilse de temelinde adrese dayalı olarak yerleştirmeler esas alınmıştır. Ortaöğretim kurumlarına hazırlanan öğrencilerin sadece yüzde 10'luk kısmının sınavla yerleşeceği ve ona göre kontenjan belirleneceği, geri kalan yüzde 90'lık kısmının ise mahalli yerleştirmeleri tercih edeceği açıklanmıştır (Yılmaz, 2017). Bu çalışmada, TEOG ve LGS sisteminin en çok kabul ve ret gören özellikleri öğrencilerin, öğretmenlerin, velilerin ve öğretmen velilerin görüşleri doğrultusunda incelenmiştir. Yeni bir sistem olarak karşımıza çıkan LGS sisteminin TEOG sistemine göre artı ve eksileri belirlenmiş, olumlu ve olumsuz yönleri tespit edilmiştir. Bu yönüyle çalışmanın ortaöğretime geçiş sınav sistemlerinin hazırlanma sürecine katkı sağlayacağı düşünülmektedir.

\section{Yöntem}

Bu bölümde; araştırmanın modeli, araştırmanın çalışma grubu, verilerin toplanması ve analizi hakkında bilgiler verilmiştir.

\section{Araștırmanın Modeli}

Araştırmada nicel ve nitel araştırma yaklaşımları birlikte kullanılmış olup TEOG ve LGS sistemlerinin yapısı öğrenci, öğretmen, veli ve öğretmen velilerin görüşleri açısından incelendiğinden 
nicel araştırma modellerinden tarama modeli, nitel araştırma modellerinden ise durum çalışması modeli kullanılmıştır. Tarama modelleri, bir konu üzerinde mevcut olan görüşleri, ilgileri, becerileri ve tutumları belirlemeyi amaçlayan bir modeldir (Karasar, 2005). Durum çalışması modeli ise sınırlı bir sistemin derinlemesine betimlenmesi ve incelenmesi olarak tanımlamaktadır (Merriam, 2013).

\section{Çalışma Grubu}

Araştırma 2018-2019 eğitim öğretim y1lında Türkiye'de yürütülmüş ve nicel kısmında Google form yardımıyla hazırlanan anket sosyal medya aracılığı ile paylaşılmış ve yedi coğrafi bölgede yer alan toplam 39 ile ulaşılmıştır. Kolay ulaşılabilir örnekleme yötemi ile ortaokul 8.sınıf öğrencileri, öğretmenleri, velileri ve aynı zamanda öğretmen olan 8. Sınıf velileri araştırmaya dâhil edilmiştir. Kolay ulaşılabilir örneklem yöntemi, zaman para ve iş gücü açısından tasarruf etmek amacıyla yapılan olasılıklı olmayan bir örnekleme yöntemidir (Miles ve Huberman, 1994; Patton, 2005). Toplam 415 kişiden oluşan çalışma grubuna ilişkin frekans dağılımı Tablo 1'de görülmektedir.

Tablo 1

Çalışma Grubuna İlişskin Frekans Dağılımı

\begin{tabular}{lcccccc}
\hline & Öğrenci & Öğretmen & Veli & $\begin{array}{c}\text { Öğretmen } \\
\text { Veli }\end{array}$ & Toplam \\
\hline \multirow{2}{*}{ Cinsiyet } & Kadın & 45 & 73 & 55 & 15 & 243 \\
& Erkek & 67 & 56 & 33 & 8 & 172 \\
\hline Toplam & & 112 & 129 & 88 & 23 & 415 \\
\hline
\end{tabular}

Araştırmanın nitel kısmında ise İç Anadolu bölgesindeki bir ilde yer alan üç ortaokul uygulamaya dâhil edilmiştir. Kolay ulaşılabilir örnekleme yöntemi ile $15^{\prime}$ er kişiden oluşan 8 .sınıf öğrencilerine, öğretmenlerine, velilerine ve aynı zamanda öğretmen olan 8. Sınıf velilerine ulaşılmıştır Toplam 60 (Kadın:33, Erkek:27) kişiden oluşan katılımcılara ilişkin frekans dağılımı Tablo 2'de sunulmuştur.

Tablo 2

Katılımcılara İlişkin Frekans Dağıllımı

\begin{tabular}{lcccccc}
\hline & & Öğrenci & Öğretmen & Veli & $\begin{array}{c}\text { Öğretmen } \\
\text { Veli }\end{array}$ & Toplam \\
\hline \multirow{2}{*}{ Cinsiyet } & Kadın & 8 & 6 & 10 & 9 & 33 \\
& Erkek & 7 & 9 & 5 & 6 & 27 \\
\hline Toplam & & 15 & 15 & 15 & 15 & 60 \\
\hline
\end{tabular}

\section{Verilerin Toplanması ve Analizi}

Nicel veriler anket yöntemi kullanılarak toplanmış ve betimsel istatistiklerden yararlanarak analiz edilmiştir. Betimleme sürecinde öncelikle TEOG ve LGS sistemleri ile ilgili literatür taranmış ve araştırmacılar tarafından 28 maddelik bir havuz oluşturulmuştur. Maddelerin yazım kuralına uygunluğu ve amaca yönelik olup olmadığ alanlarında uzman üç öğretim üyesinin görüşü doğrultusunda incelenmiş ve gerekli düzenlemeler yapılmıştır. İki madde anlam yönünden diğer maddeler ile benzerlik göstermesi ve bir maddenin de uzmanlar arasında görüş ayrılığına sebep olması nedeniyle anketten çırakılmıştır. Sonuç olarak 25 maddelik bir anket ortaya çıkmıştır. Google form yardımıyla hazırlanan bu anket " "Katılmıyorum", Kararsızım" ve "Katıllyorum" şeklinde derecelendirilmiş ve öğrenci, öğretmen, veli ve öğretmen velilere sosyal medya aracılığı ile çevrimiçi olarak uygulanmıştır. Elde edilen veriler Microsoft Excel programına aktarılmış ve her bir maddenin öğrenci, öğretmen, veli ve öğretmen veliler açısından frekansları hesaplanmıştır. Ayrıca, öğrenci, öğretmen, veli ve öğretmen velilerin TEOG ve LGS sistemlerini beş üzerinden puanlamaları istenmiştir. Böylece her iki sistemin ortalama puanları hesaplanarak karşılaştırmaları yapılmış ve öğrenci, öğretmen, veli ve öğretmen veliler açısından daha çok tercih edilen sistem nedenleriyle birlikte belirlenmiştir. 
Diğer taraftan, 15 'er kişiden oluşan öğrenci, öğretmen, veli ve öğretmen velilere "İyi bir sınav sistemi nasıl olmalıdır?" sorusu yazılı olarak yöneltilmiş ve sınav sistemleri ile ilgili görüşleri alınmıştır. Görüşme sonucunda elde edilen nitel verilerin çözümlenmesinde içerik analizi ve tümevarımcı analiz teknikleri kullanılmıştır. İçerik analizi, elde edilen verilerin anlamlandırılması sonucunda belirli kavram ve temalar ile çerçeve oluşturulması ve ortaya çıan durumun anlaşılabilir şekilde kategorilere ayrılarak somutlaştırılmasıdır (Yaman, 2010). "Tümevarımcı analiz ise kodlama yoluyla verilerin altında yatan kavramları ve bu kavramlar arasındaki ilişkileri ortaya çıkarmaktır" (Yıldırım ve Şimşek, 2005, s.227). İçerik analizi sonucunda ortaya çıkan kodlar ve temalar katılımcıların verdiği yanıtlardan çıkarılmış ve araştırmacılar tarafından birbirinden bağımsız şekilde bir kavramsal kategori altında toplanmıştır. Araştırmacılar tarafından ulaşılan kavramsal kategori altındaki kodların ilgili kavramsal kategoriyi temsil edip etmediğini incelemek amacıyla ortaya çıkan kodlar karşılaştırılmış ve kodlayıcılar arası güvenirlik Kendall W testi ile .82 olarak bulunmuştur. Kodlayıcılar arası güvenirliğin en az .80 olması gerektiği ifade edilmiştir (Howell, 2013; Salkind, 2010; Szymanski ve Linkowski, 1993). Görüş ayrılıklarına neden olan kodlar ise araştırmacılar tarafından tartışılmış ve ortak bir yargı ile uygun kategoriler altına yerleştirilmiştir. Herbir kodun yüzde ve frekans dağılımları SPSS 23 programı ile hesaplanmış ve "Sınav Koordinatörlüğ̈̈", "Sınav Sayısı", "Soru Dağılımı", "Soru Tipi" ve "Yerleştirme Tipi" şeklinde kavramsal kategoriler oluşturulmuştur.

\section{Bulgular ve Yorum}

$\mathrm{Bu}$ araştırmada, TEOG ve LGS sistemlerinin özellikleri ile ilgili maddelerden oluşan bir anket hazırlanmış ve öğrenci, öğretmen, veli ve öğretmen velilere uygulanarak en çok kabul ve ret gören özellikleri belirlenmiştir. Her bir maddenin öğrenci, öğretmen, veli ve öğretmen veli açısından frekans dağılımı Tablo 3'de sunulmuştur.

Tablo 3

Maddelerin Ö̈rrenci, Ögrretmen, Veli ve Ögrretmen Velilere Göre Frekans Dă̆llımı

\begin{tabular}{|c|c|c|c|c|c|c|c|c|c|c|c|c|}
\hline \multirow[b]{2}{*}{ Madde } & \multicolumn{3}{|c|}{ Öğrenci } & \multicolumn{3}{|c|}{ Öğretmen } & \multicolumn{3}{|c|}{ Veli } & \multicolumn{3}{|c|}{ Öğretmen-Veli } \\
\hline & - & o & + & - & о & + & - & $\mathbf{0}$ & + & - & $\mathbf{0}$ & + \\
\hline M1 & 52 & 24 & 36 & 83 & 13 & 33 & 59 & 12 & 17 & 13 & 2 & 8 \\
\hline M2 & 89 & 6 & 17 & 80 & 13 & 36 & 61 & 10 & 17 & 18 & 0 & 5 \\
\hline M3 & 24 & 14 & 74 & 48 & 11 & 70 & 42 & 9 & 37 & 10 & 2 & 11 \\
\hline M4 & 66 & 16 & 30 & 106 & 11 & 12 & 65 & 5 & 18 & 20 & 2 & 1 \\
\hline M5 & 31 & 19 & 62 & 26 & 9 & 94 & 14 & 10 & 64 & 3 & 4 & 16 \\
\hline M6 & 18 & 20 & 74 & 37 & 17 & 75 & 26 & 12 & 50 & 6 & 1 & 16 \\
\hline M7 & 59 & 13 & 40 & 73 & 17 & 39 & 40 & 13 & 35 & 9 & 2 & 12 \\
\hline M8 & 48 & 15 & 49 & 42 & 9 & 78 & 41 & 6 & 41 & 7 & 1 & 15 \\
\hline M9 & 14 & 3 & 95 & 60 & 6 & 63 & 19 & 5 & 64 & 6 & 2 & 15 \\
\hline M10 & 38 & 28 & 46 & 31 & 11 & 87 & 18 & 14 & 56 & 7 & 2 & 14 \\
\hline M11 & 9 & 11 & 92 & 41 & 9 & 79 & 16 & 6 & 66 & 5 & 1 & 17 \\
\hline M12 & 26 & 19 & 67 & 25 & 24 & 80 & 22 & 10 & 56 & 2 & 2 & 19 \\
\hline M13 & 29 & 10 & 73 & 28 & 17 & 84 & 29 & 13 & 46 & 9 & 5 & 9 \\
\hline M14 & 31 & 14 & 67 & 4 & 4 & 121 & 6 & 10 & 72 & 0 & 0 & 23 \\
\hline M15 & 45 & 19 & 48 & 37 & 19 & 73 & 16 & 10 & 62 & 3 & 1 & 19 \\
\hline M16 & 15 & 8 & 89 & 23 & 10 & 96 & 11 & 8 & 69 & 3 & 0 & 20 \\
\hline M17 & 38 & 26 & 48 & 24 & 10 & 95 & 21 & 10 & 57 & 6 & 3 & 14 \\
\hline M18 & 41 & 16 & 55 & 32 & 4 & 93 & 27 & 11 & 50 & 7 & 2 & 14 \\
\hline M19 & 13 & 12 & 87 & 30 & 17 & 82 & 13 & 17 & 58 & 2 & 1 & 20 \\
\hline M20 & 58 & 23 & 31 & 88 & 11 & 30 & 44 & 9 & 35 & 13 & 0 & 10 \\
\hline M21 & 23 & 19 & 70 & 79 & 28 & 22 & 32 & 20 & 36 & 14 & 2 & 7 \\
\hline M22 & 41 & 10 & 61 & 20 & 6 & 103 & 14 & 12 & 62 & 5 & 0 & 18 \\
\hline M23 & 35 & 16 & 61 & 58 & 12 & 59 & 43 & 4 & 41 & 10 & 4 & 9 \\
\hline M24 & 16 & 12 & 84 & 29 & 14 & 86 & 21 & 11 & 56 & 4 & 1 & 18 \\
\hline M25 & 41 & 14 & 57 & 62 & 12 & 55 & 44 & 6 & 38 & 12 & 1 & 10 \\
\hline
\end{tabular}

- : Katılmıyorum o : Kararsızım + : Katılıyorum

Tablo 3'de ayrıntılı olarak verilen maddelerin frekans dağılımı öğrenciler, öğretmenler, veliler 
ve öğretmen veliler için ayrı ayrı sunulmuştur.

Tablo 4.

Öğrencilere Göre En Çok Kabul v Ret Gören Maddeler

\begin{tabular}{llcc}
\hline & \multicolumn{1}{c}{ En çok kabul edilen 5 madde } & f & \% \\
\hline M9 & Yanlış yapılan sorular doğru soruları götürmemelidir. & 95 & 84.8 \\
M11 & Öğrenciler sınava kendi okullarında girmelidir. & 92 & 82.1 \\
M16 & Sinava giremeyen öğrenciler için mazeret sınavı yapılmalıdır. & 89 & 79.5 \\
M19 & Sınav sadece çoktan seçmeli sorulardan oluşmalıdır. & 87 & 77.7 \\
M24 & Öğrenciler bir oturumda en fazla 3 dersin sınavına girmelidir. & 84 & 75 \\
\hline & \multicolumn{1}{c}{ En çok reddedilen 5 madde } & f & \% \\
\hline M2 & Sınavda çoktan seçmeli sorularla birlikte açık uçlu sorulara da yer verilmelidir. & 89 & 79.5 \\
M4 & Ortaöğretim okulları kendi sınavını kendileri yapmalıdır. & 66 & 58.9 \\
M7 & Bazı liseler tarafından yapıllan sınavlar bütün liseler için geçerli sayıllmalıdır. & 59 & 52.7 \\
M20 & Ortaöğretime geçiş için yapılan sınav tek bir oturumda tamamlanmalıdır. & 58 & 51.8 \\
M1 & Öğrenci adresine en yakın okula kayıt yaptırmalıdır. & 52 & 46.4 \\
\hline
\end{tabular}

Tablo 4 incelendiğinde, öğrencilere göre "Yanlış yapılan sorular doğru soruları götürmemelidir" maddesi \%84.8 ( $\mathrm{f}=95)$ ile ilk sırada yer alırken; "Sınavda çoktan seçmeli sorularla birlikte açık uçlu sorulara da yer verilmelidir" maddesi \%79.5 (f=89) ile son sırada yer almıştır. Öğrencilerin \%77.7 (f=87)'si sınavın sadece çoktan seçmeli sorulardan oluşması gerektiğini düşünmüştür. Ayrıca, öğrencilerin \%51.8 ( $\mathrm{f}=58)$ 'i sinavların tek oturumda olmaması gerektiğini, \%75 ( $\mathrm{f}=84)^{\prime} \mathrm{i}$ ise bir oturumda en fazla üç dersin sınavının yapılması gerektiğini belirtmitir. Öğrencilerin \%82.1 (f=92)'i kendi okullarında sınava girmeyi tercih etmesine rağmen, öğrencilerin \%58.1 ( $\mathrm{f}=66)$ 'i sınavların kendi okulları tarafından hazırlanmasını tercih etmemektedir. Ayrıca, öğrencilerin \%79.5 ( $\mathrm{f}=89$ )'i sınava giremeyen öğrenciler için mazeret sınavının yapılması gerektiğini düşünmektedir. Öğrencilerin \%46.4 (f=52)'ü ise üdrese en yakın okula kayıt yaptırılmasını çok uygun görmemektedir. Öğrencilerin sınav sistemine dair düşüncelerini incelemek için ise "İyi bir sınav sistemi nasıl olmalıdır?" sorusu yöneltilmiş ve görüşleri alınmıştır. Öğrencilerden alınan bazı görüşler aşağıda sunulmuştur.

ö1: "Sinav soruları MEB tarafindan hazırlanmall, ancak yazll slnavlar gibi ders saatinde ögretmenler tarafindan yapılmalıdır."

ö3: "Sinavlar her yarlyılda 2 veya 3 kez yapılmalıdır."

ö4: "Sinav soruları sadece 8. Sinıf müfredatını değil, 6. ve 7. Sinıf müfredatını da içermelidir."

ö5: "Her dersin soru sayısı ayn olmamalı, dersin önemine ve dönemi içi ağırlı̆ğına göre soru sayıları belirlenmelidir."

ö8: "T.C. Inkılap Tarihi ve Atatürkçülük dersinin soru sayısı arttırllarak 10'dan fazla olmalıdır."

ö10: "Öğrenme güçlüğü olan ögrenciler de düşünülerek sinav soruları hazırlanmalıdır."

ö12: "Açık uçlu sorular yerine sadece çoktan seçmeli sorular sorulmalıdır."

ö13: "Her ögrrenci kendi okullunda sinavina girmeli, ancak gözetmenler farklı okullarda görev yapan ögretmenler olmalıdır."

Öğrenciler ile yapılan görüşmeler sonucunda TEOG ve LGS sistemlerine dair olumlu ve olumsuz düşüncelerin olduğu görülmektedir. $\ddot{o} 1$, ö3 ve $\ddot{o} 13$ kodlu öğrenciler TEOG sisteminde yer alan ve LGS sistemi ile beraber değişikliğe uğrayacak olan bazı özelliklere dikkat çekmiştir. $\ddot{o} 4$ ve $\ddot{o} 5$ kodlu öğrenciler ise LGS sistemi ile beraber uygulanmaya başlanan bazı özellikleri olumlu görmüştür. ö8 kodlu öğrenci ise T.C. İnkılap Tarihi ve Atatürkçülük dersinin soru sayısının arttırılması gerektiğine vurgu yapmış ve bu durumun LGS sisteminin olumsuz bir yönü olduğunu düşünmüştür. ö10 kodlu öğrenci öğrenme güçlüğü çeken öğrencilerin de düşünülmesi ve soruların bu öğrencileri de kapsayacak şekilde hazırlanması gerektiğini, ö12 kodlu öğrenci ise hazırlanan sınav sorularının sadece çoktan seçmeli sorulardan oluşması gerektiğini belirtmiştir. 
Tablo 5

Ögretmenlere Göre En Çok Kabul ve Ret Gören Maddeler

\begin{tabular}{|c|c|c|c|}
\hline \multicolumn{2}{|r|}{ En çok kabul edilen 5 madde } & \multirow{2}{*}{\begin{tabular}{c|}
$\mathbf{f}$ \\
121
\end{tabular}} & \multirow{2}{*}{$\begin{array}{c}\% \\
93.8\end{array}$} \\
\hline M14 & Fen lisesi gibi özel nitelik gerektiren okullara sınavla öğrenci alınmalıdır. & & \\
\hline M22 & 6. 7. ve 8. Sınıf not ortalamaları değerlendirmeye alınmalıdır. & 103 & 79.8 \\
\hline M16 & Sınava giremeyen öğrenciler için mazeret sınavı yapılmalıdır. & 96 & 74.4 \\
\hline M17 & $\begin{array}{l}\text { Din Kültürü ve Ahlak Bilgisi dersi için farklı dine mensup öğrenciler de düşünülerek daha } \\
\text { genel sorular sorulmalıdır. }\end{array}$ & 95 & 73.6 \\
\hline M5 & Ortaokul başarı ölçütleri ortaöğretim okullarına yerleştirmede hesap edilmelidir. & 94 & 72.9 \\
\hline \multicolumn{2}{|r|}{ En çok reddedilen 5 madde } & $\mathbf{f}$ & $\%$ \\
\hline M4 & Ortaöğretim okulları kendi sınavını kendileri yapmalıdır. & 106 & 82.2 \\
\hline M20 & Ortaöğretime geçiş için yapılan sınav tek bir oturumda tamamlanmalıdır. & 88 & 68.2 \\
\hline M1 & Öğrenci, adresine en yakın okula kayıt yaptırmalıdır & 83 & 64.3 \\
\hline M2 & Sınavda çoktan seçmeli sorularla birlikte açık uçlu sorulara da yer verilmelidir. & 80 & 62 \\
\hline M21 & Sınavda toplam 90 sorunun olması başarıyı ölçmek için yeterlidir. & 79 & 61.2 \\
\hline
\end{tabular}

Tablo 5 incelendiğinde, öğretmenlere göre "Fen lisesi gibi özel nitelik gerektiren okullara sınavla öğrenci alınmalıdır" maddesi \%93.8 ( $\mathrm{f}=121)$ ile ilk sırada yer alırken; "Ortaöğretim okulları kendi sınavını kendileri yapmalıdır" maddesi \%82.2 (f=106) ile son sırada yer almıştır. Öğretmenlerin \%61.2 (f=79)'si toplam 90 sorunun başarıyı ölçmek için yeterli sayıda olmadığını, \%52 ( $\mathrm{f}=80$ )'si ise açık uçlu soruların sorulmasının çok uygun olmadığını belirtmiştir. Ayrıca, öğretmenlerin \%74.4 $(\mathrm{f}=96)$ ' $\mathrm{ü} \mathrm{sınava} \mathrm{giremeyen} \mathrm{öğrenciler} \mathrm{için} \mathrm{mazeret} \mathrm{sınavının} \mathrm{yapılması} \mathrm{gerektiğini} \mathrm{düşünürken,} \% 64.3$ $(\mathrm{f}=83$ )' $\mathrm{ü}$ adrese en yakın okula kayıt yaptırılmasını çok uygun görmemiştir. Öğretmenlerin \%79.8 (f=103)'si 6. 7. ve 8. Sinıf not ortalamalarının değerlendirmeye alınması gerektiğini, \%73.6 (f=95)'s1 ise Din Kültürü ve Ahlak Bilgisi dersi için farklı dine mensup öğrenciler de düşünülerek daha genel soruların sorulması gerektiğini belirtmiştir. Öğretmenlerin sınav sistemine dair düşüncelerini incelemek için ise "İyi bir sınav sistemi nasıl olmalıdır?" sorusu yöneltilmiş ve görüşleri alınmıştır. Öğretmenlerden alınan bazı görüşler aşağıda sunulmuştur

Ö1: "Sinavlar MEB tarafindan merkezi olarak yapılmalıdır. Öğretmenler sinav yapmamalı ve yapılan sınavlarda görev almamalıdır. Öğretici ve eğitici olarak görevini yerine getirmelidir."

Ö2: "Açık uçlu soruların cevabı kisa ve net olduğu için amacına ulaşamamakta, çoktan seçmeli soru tarzını çă̆rıştırmaktadır. Bu sebeple, açık uçlu sorular yerine sadece çoktan seçmeli sorular sorulmalıdır."

Ö3: "Okullarda yapılan yazılılar sadece klasik sinav şeklinde olmalı ve ögrencilerin kendini ifade etme becerileri geliştirilmelidir."

Ö5: "Mazeret sinavi yerine herkesin girebileceği iki merkezi sınav yapılmalı ve yüksek puan esas alınmalıdır."

Ö7: "Liseler, meslek ve genel olacak şekilde iki sınıfa ayrılmalıdır. Aynı eğitim programına dâhil liseler için tekrar sınıf ayrımı yapılmamalıdır."

Ö8: "Aynı eğitim programına sahip liseler aynı düzeyde eğitim vermeli ve ona göre kadrolaşmalıdır. Eğitim düzeyi aynı olan okullar için sinav uygulaması kalkmalıdır."

Ö12: "Öğrenciler, aynı ĕgitim programına dâhil liseler için istediği tercihi yapabilmelidir."

Öğretmenler ile yapılan görüşmeler sonucunda sınav sistemine yönelik çeşitli öneriler ortaya çıkmıştır. Ö1 kodlu öğretmen TEOG sistemindeki gibi bir merkezi sınav sisteminin olması gerektiğine vurgu yapmış ancak bu sınavlarda öğretmenlerin görev almaması gerektiğini önermiştir. Ö2 kodlu öğretmen yapılan sınavların sadece çoktan seçmeli sorulardan oluşması gerektiğini, Ö3 kodlu öğretmen ise okulllarda yapılan yazılıların sadece klasik sınav şeklinde olması gerektiğini belirtmiştir. TEOG sisteminde uygulanan mazeret sınavları $\ddot{O} 5$ kodlu öğretmen tarafindan eleştirilmiş ve mazeret sınavı yerine herkesin girebileceği ve yüksek puanın geçerli sayılacağı ikinci bir merkezi sınavın yapılmas1 gerektiği önerilmiştir. $\ddot{O} 7, \ddot{O} 8$ ve $\ddot{O} 12$ kodlu öğretmenler ise aynı eğitim programına dâhil liseler için öğrencilerin istediği tercihi yapabilmesi gerektiğini, bu okullar için sınav uygulamasına gerek olmadığını vurgulamışlardır. 
Tablo 6

Velilere Göre En Çok Kabul ve Ret Gören Maddeler

\begin{tabular}{llcc}
\hline & \multicolumn{1}{c}{ En çok kabul edilen 5 madde } & f & \% \\
\hline M14 & Fen lisesi gibi özel nitelik gerektiren okullara sınavla öğrenci alınmalıdır. & 72 & 81.8 \\
M16 & 6. 7. ve 8. Sınıf not ortalamaları değerlendirmeye alınmalıdır. & 69 & 78.4 \\
M11 & Sınava giremeyen öğrenciler için mazeret sınavı yapılmalıdır. & 66 & 75 \\
M5 & Ortaokul başarı ölçütleri ortaöğretim okullarına yerleştirmede hesap edilmelidir. & 64 & 72.7 \\
M9 & Yanlış yapılan sorular doğru soruları götürmemelidir. & 64 & 72.7 \\
\hline & & En çok reddedilen 5 madde & f \\
\hline M4 & Ortaöğretim okulları kendi sınavını kendileri yapmalıdır. & 65 & 73.9 \\
M2 & Sınavda çoktan seçmeli sorularla birlikte açık uçlu sorulara da yer verilmelidir. & 61 & 69.3 \\
M1 & Öğrenci adresine en yakın okula kayıt yaptırmalıdır. & 59 & 67 \\
M20 & Ortaöğretime geçiş için yapılan sınav tek bir oturumda tamamlanmalıdır. & 44 & 50 \\
M25 & Sınav soruların dağılımı sınıf düzeylerine göre eşit sayıda olmalıdır. & 44 & 50 \\
\hline
\end{tabular}

Tablo 6 incelendiğinde, öğretmenlerde olduğu gibi velilere göre de "Fen lisesi gibi özel nitelik gerektiren okullara sinavla öğrenci alınmalıdır" maddesi \%81.8 ( $\mathrm{f}=72)$ ilk sırada yer alırken; "Ortaöğretim okulları kendi sınavını kendileri yapmalıdı"” maddesi \%82.1 (f=92) son sırada yer almıştır. Velilerin \%72.7 (f=62)'si yanlış yapılan soruların doğru cevap sayısını etkilememesi gerektiğini, \%75 ( $\mathrm{f}=66)$ 'i ise sınava giremeyen öğrenciler için mazeret sınavının yapılması gerektiğini belirtmiştir. Ayrıca, velilerin \%78.4 (f=69)'ü 6. 7. ve 8. Sınıf not ortalamalarının değerlendirmeye alınması gerektiğini; \%50 ( $\mathrm{f}=44)$ 'si ise sınav soru sayılarının dağılımının sınıf düzeyine göre eşit sayıda olmaması gerektiğini düşünmektedir. Velilerin \%69.3 ( $\mathrm{f}=61)$ 'ü açık uçlu soruların sorulmasını, $\% 67$ ( $\mathrm{f}=59$ )'si ise adrese en yakın okula kayıt yaptırılmasını çok uygun görmemektedir. Velilerin sınav sistemine dair düşüncelerini incelemek için ise "İyi bir sınav sistemi nasıl olmalıdır?" sorusu yöneltilmiş ve görüşleri alınmıştır. Velilerden alınan bazı görüşler aşağıda sunulmuştur.

V3: "Değişen sınav sistemleri aynı yıl yerine sonraki yıllarda kademeli olarak uygulanmaya başlanmalıdır."

V4: "Sinavlarda yanlış cevap sayısı doğru cevap sayısını etkilememeli, sorular öğrencilerin aldı̆̆ eğitime ve müfredata uygun şekilde hazırlanmalıdır."

V9: "5-8 her yılsonunda sinav yapılmal ve ortalamaları alınarak genel başart puanı belirlenmelidir. Böylece başarının tesadüfi olmadı̆̆ı, devamlılık arz ettiği görülmelidir."

V14: "Fen Lisesi ve diğer başarılı okullar için sinav yapılmalıdır. Adrese dayal yerleşme zengin ve fakir sını ayrımına sebep olacağı için tercih edilmemelidir."

Veliler ile yapılan görüşmeler socunda $V 3$ kodlu veli önemli bir noktaya değinmiş ve değişen sınav sistemlerinin sonraki yıllarda kademeli olarak uygulanmaya başlanması gerektiği belirtilmiştir. Düzeltme formülünün uygulanacağı ve 3 yanlışın 1 doğru cevabı götüreceği LGS sistemi bu yönüyle V4 kodlu bir veli tarafından eleştirilmiş ve yanlış cevapların doğru cevapları etkilememesi gerektiği belirtilmiştir. V9 kodlu veli tarafindan başarının tek bir sınava bağlı olmaması gerektiği vurgulanmış ve her yıl yapılan bir sınavın ortalaması alınarak yerleştirmenin yapılması gerektiği belirtilmiştir. V14 kodlu veli ise LGS sisteminin temelini oluşturan adrese dayalı sistemi sınıf ayrımına neden olacağı düşüncesiyle eleştirmiştir.

Tablo 7

Öğretmen Velilere Göre En Çok Kabul ve Ret Gören Maddeler

\begin{tabular}{llcc}
\hline & \multicolumn{1}{c}{ En çok kabul edilen 5 madde } & F & \% \\
\hline M14 & Fen lisesi gibi özel nitelik gerektiren okullara sınavla öğrenci alınmalıdır. & 23 & 100 \\
M16 & 6. 7. ve 8. Sinıf not ortalamaları değerlendirmeye alınmalıdır. & 20 & 87 \\
M19 & Sinav sadece çoktan seçmeli sorulardan oluşmalıdır. & 20 & 87 \\
M12 & Sinavda her ders için 20 soru sorulması yeterlidir. & 19 & 82.6 \\
M15 & Sinav süresinin 155 dakika olması öğrenciler için yorucu olur. & 19 & 82.6 \\
\hline
\end{tabular}




\begin{tabular}{|c|c|c|c|}
\hline & En çok reddedilen 5 madde & $\mathbf{F}$ & $\%$ \\
\hline M4 & Ortaöğretim okulları kendi sınavını kendileri yapmalıdır. & 20 & 87 \\
\hline M2 & Sınavda çoktan seçmeli sorularla birlikte açık uçlu sorulara da yer verilmelidir. & 18 & 78,2 \\
\hline M21 & Sınavda toplam 90 sorunun olması başarıyı ölçmek için yeterlidir. & 14 & 60.9 \\
\hline M1 & Öğrenci adresine en yakın okula kayıt yaptırmalıdır. & 13 & 56.5 \\
\hline M20 & Ortaöğretime geçiş için yapılan sınav tek bir oturumda tamamlanmalıdır. & 13 & 56.5 \\
\hline
\end{tabular}

Tablo 7 incelendiğinde, öğretmenler ve velilerde olduğu gibi öğretmen velilere göre de "Fen lisesi gibi özel nitelik gerektiren okullara sınavla öğrenci alınmalıdır" maddesi \%100 (f=23) ile ilk sırada yer alırken; "Ortaöğretim okulları kendi sınavını kendileri yapmalıdır" maddesi \%87 (f=20) ile son sırada yer almıştır. Öğrencilerde olduğu gibi öğretmen veliler de sınav sorularının sadece çoktan seçmeli sorulardan oluşması gerektiğini düşünmekte $(\% 87, \mathrm{f}=20)$; açık uçlu soruların olmasını çok uygun görmemektedir (\%78.2, f=18). Ayrıca, öğretmen velilerin \%60.9 ( $\mathrm{f}=14)$ 'u altı temel dersi içeren sınavın toplam 90 sorudan oluşmasını başarıyı ölçmek için yeterli görmezken, \%82.6 (f=19)'s1 her ders için 20 soru sorulmasını ve sınav süresinin 155 dakikadan az olmasını uygun görmüştür.

Öğretmen velilerin sınav sistemine dair düşüncelerini incelemek için ise "İyi bir sınav sistemi nasıl olmalıdır?" sorusu yöneltilmiş ve görüşleri alınmıştır. Öğretmen velilerden alınan bazı görüşler aşağıda sunulmuş̧tur.

ÖV2: "Sinav sorularl, eğitim programlarına uygun olarak hazırlanmalıdır."

ÖV7: "Okullarda sinav sistemine yönelik uygulamalar yapılmal,, ögretim programı, teknikleri ve kazanımları dikkate alınarak sinav soruları hazırlanmalıdır."

ÖV11: "Açık uçlu sorular sorularak analiz ve sentez basamaklarında da sorular hazırlanmall, çoktan seçmeli sorularak ile bilgi basamağında kalınmamalıdır."

ÖV12: "Değişen sinav sistemleri bir sonraki ylldan itibaren uygulamaya geçirilmelidir."

ÖV15: "Soru sayısının 10 olması bir dersi ölçmek için yetersiz kalacağından, öğrenciyi yormayacak şekilde arttırlmalı ve dersin içeriği ile uyumlu olmalıdır."

Öğretmen veliler ile yapılan görüşmeler sonucunda $O ̈ V 2$ kodlu bir veli tarafından sınav sistemlerinin eğitim programına uygun olarak hazırlanması gerektiği vurgulanmıştır. ÖV7 kodlu veli de benzer şekilde öğretim programlarına, tekniklerine ve kazanımlarına dikkat edilmesi gerektiğini belirtmiştir. ÖV11 kodlu veli açık uçlu soruları olumsuz bir uygulama olarak görmemiş sadece soruların bilişsel olarak analiz ve sentez basamaklarında hazırlanması gerektiğini ileri sürmüştür. ÖV12 kodlu veli V3 kodlu veli gibi değişen sınav sistemlerinin sonraki yıllarda hayata geçirilmesi gerektiğini belirtmiştir. Ayrıca, ÖV15 kodlu veli de ö8 kodlu öğrenci gibi 10 soru ile bilgiyi ölçmenin yetersiz olacağını vurgulamıştır.

Öğrenci, öğretmen, veli ve öğretmen-veli açısından maddelerin önem durumu incelendiğinde iki veya daha fazla katılımcı ile ilişkili olan maddeler Tablo 8'de sunulmuştur.

Tablo 8

Öğrenci, Öğretmen, Veli ve Öğretmen Veliler Açısından En Yüksek Ve En Düşük Ortalamalı Maddeler

\begin{tabular}{|c|c|c|c|c|c|}
\hline & Maddeler & 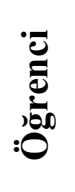 & Ō: & $\bar{j}^{\circ}$ & 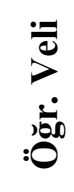 \\
\hline & En çok kabul edilen maddeler & \multicolumn{4}{|c|}{ Siralamalar } \\
\hline M9 & Yanlış yapılan sorular doğru soruları götürmemelidir. & 1 & & 4 & \\
\hline M11 & Öğrenciler sınava kendi okullarında girmelidir. & 2 & & 3 & \\
\hline M14 & Fen lisesi gibi özel nitelik gerektiren okullara sınavla öğrenci alınmalıdır. & & 1 & 1 & 1 \\
\hline M16 & Sınava giremeyen öğrenciler için mazeret sınavı yapılmalıdır. & 3 & 3 & 2 & 2 \\
\hline M19 & Sınav sadece çoktan seçmeli sorulardan oluşmalıdır. & 4 & & & 3 \\
\hline
\end{tabular}




\begin{tabular}{llllll}
\hline \multicolumn{1}{c}{ En çok reddedilen maddeler } & & & \\
\hline M1 & Öğrenci adresine en yakın okula kayıt yaptırmalıdır & 5 & 3 & 3 & 4 \\
M2 & Sinavda çoktan seçmeli sorularla birlikte açık uçlu sorulara da yer verilmelidir. & 1 & 4 & 2 & 2 \\
M4 & Ortaöğretim okulları kendi sınavını kendileri yapmalıdır. & 2 & 1 & 1 & 1 \\
M20 & Ortaöğretime geçiş için yapıllan sınav tek bir oturumda tamamlanmalıdır. & 4 & 2 & 4 & 5 \\
M21 & Sınavda toplam 90 sorunun olması başarııı ölçmek için yeterlidir. & 5 & & 3 \\
\hline
\end{tabular}

Tablo 8 incelendiğinde en çok kabul gören maddelerin çoğunlukla TEOG sistemine ait özellikleri içeren maddeler olduğu; düşük ortalamaya sahip maddelerin ise çoğunlukla LGS sistemine ait özellikleri içeren maddeler olduğu görülmektedir. Bu bağlamda, öğrenci, öğretmen, veli ve öğretmen velilerin TEOG ve LGS sistemlerini beş üzerinden puanlamaları istenmiş ve elde edilen ortalama puanlar Tablo 9'de verilmiştir.

Tablo 9

Öğrenci, Ögrretmen, Veli ve Öğretmen Velilerin TEOG ve LGS Sistemlerine Ait Ortalama Puanlar

\begin{tabular}{llccccc}
\hline & & Öğrenci & Öğretmen & Veli & Öğr-Veli & Toplam \\
\hline \multirow{2}{*}{ Sinav Sistemleri } & TEOG & 3,63 & 3,54 & 3,63 & 3,82 & 3,57 \\
& LGS & 2,81 & 2,69 & 2,84 & 2,65 & 2,73 \\
\hline
\end{tabular}

Tablo 9'a göre, öğrenci, öğretmen, veli ve öğretmen veliler LGS sistemine göre TEOG sistemine daha pozitif düşünceler beslemekte ve daha uygun bir sınav sistemi olarak görmektedir. Ayrıca, öğrenci, öğretmen, veli ve öğretmen velilerin sınav sistemine dair düşüncelerini incelemek için sorulan "İyi bir sınav sistemi nasıl olmalıdır?" sorusuna ait kavramsal kategoriler oluşturulmuş ve Tablo 10’da sunulmuştur.

Tablo 10

Ö̆rrenci, Öğretmen, Veli ve Öğretmen Velilerin Görüsslerine Yönelik Ortaya Çıkan Kavramsal Kategoriler Ve Temaların Yüzde Dağılımı

\begin{tabular}{|c|c|c|c|c|c|}
\hline Kavramsal Kategoriler & Temalar & $\ddot{0}$ & $\ddot{\mathbf{O}}$ & V & ÖV \\
\hline $\begin{array}{l}\text { Sinav Koordinatörlüğü } \\
\text { ö1,ö2,ö13,Ö1 }\end{array}$ & $\begin{array}{l}\text { Sınav soruları MEB tarafindan hazırlanmalı } \\
\text { Öğretmenler sınavda görev almalı } \\
\text { Öğretmenler sınavda görev almamalı } \\
\text { Öğrenciler kendi okulunda sınava girmeli }\end{array}$ & $\begin{array}{l}11.8 \\
17.6\end{array}$ & 4.8 & & \\
\hline Toplam & & 29.4 & 9.6 & & \\
\hline $\begin{array}{l}\text { Sinav Sayısı } \\
\text { ö3,Ö5,Ö6,V8,V9,ÖV5 }\end{array}$ & $\begin{array}{l}\text { Sinavlar her yarıyılda birkaç kez yapılmalı } \\
\text { Mazeret sinavı yerine iki merkezi sınav yapılmalı }\end{array}$ & 5.9 & 9.5 & 9.1 & 5 \\
\hline Toplam & & 5.9 & 9.5 & 9.1 & 5 \\
\hline $\begin{array}{l}\text { Soru Dağılımı } \\
\text { ö4-ö8,ÖV6,ÖV15 }\end{array}$ & $\begin{array}{l}\text { Sinav soruları 6. 7. ve 8. sınıf müfredatını içermeli } \\
\text { Soru sayısı dersin ağırlığına göre olmalı }\end{array}$ & $\begin{array}{ll}5.9 \\
23.5\end{array}$ & & & 10 \\
\hline Toplam & & 29.4 & & & 10 \\
\hline $\begin{array}{l}\text { Soru Tipi } \\
\text { ö9-ö12,ö14,ö15, Ö2- } \\
\text { Ö4,V4-V7, ÖV1- } \\
\text { ÖV4,ÖV7, } \\
\text { ÖV8,ÖV11,ÖV15 }\end{array}$ & $\begin{array}{l}\text { Sorular öğrenci seviyesine uygun olmalı } \\
\text { Açık uçlu sorular yerine çoktan seçmeli sorular sorulmalı } \\
\text { Çoktan seçmeli sorular yerine açı uçlu sorular sorulmalı } \\
\text { Sorular için düzeltme formülü uygulanmamalı } \\
\text { Sorular ders içeriği ile uyumlu olmalı }\end{array}$ & $\begin{array}{l}17.6 \\
17.6\end{array}$ & $\begin{array}{l}9.5 \\
4.8\end{array}$ & $\begin{array}{l}18.2 \\
4.5\end{array}$ & $\begin{array}{l}5 \\
5 \\
5 \\
25\end{array}$ \\
\hline Toplam & & 35.2 & 14.3 & 22.7 & 40 \\
\hline $\begin{array}{l}\text { Yerleştirme Tipi } \\
\text { Ö7-Ö15,V1-V3,V10- } \\
\text { V15,ÖV9,ÖV10 } \\
\text { ÖV12-ÖV14 }\end{array}$ & $\begin{array}{l}\text { Liseler, meslek ve genel lise olacak şekilde iki sınıfa } \\
\text { ayrılmalı } \\
\text { Aynı eğitim programına sahip okullar için sınav } \\
\text { yapılmamalı } \\
\text { Değişen sınav sistemleri bir sonraki yıldan itibaren }\end{array}$ & & 14.3 & 13.6 & 5 \\
\hline
\end{tabular}




\begin{tabular}{|c|c|c|c|c|}
\hline & $\begin{array}{l}\text { Nitelikli okullar için sınav yapılmalı } \\
\text { Adrese dayalı yerleştirme yapılmamalı }\end{array}$ & $\begin{array}{l}19 \\
19 \\
\end{array}$ & $\begin{array}{l}27.3 \\
27.3 \\
\end{array}$ & $\begin{array}{l}20 \\
20\end{array}$ \\
\hline Toplam & & 66.6 & 68.2 & 45 \\
\hline
\end{tabular}

Tablo 10 incelendiğinde öğrenci, öğretmen, veli ve öğretmen velilerin görüşleri "Sınav Koordinatörlüğü", "Sınav Sayısı", "Soru Dağılımı", "Soru Tipi” ve "Yerleştirme Tipi” kategorileri altında toplanmıştır. Öğrencilerin \%35.2'si "Soru Tipi” kategorisi altındaki temalarda yoğunlaşırken, öğretmenlerin \%66.6's1, velilerin \%71.5'i, öğretmen velilerin ise \%45'i "Yerleştirme Tipi" kategorisi altındaki temalarda yoğunlaşmıştır. Öğrenciler içerisinde en fazla yoğunlaşılan tema \%23.5 ile "Soru sayısı dersin ağırlığına göre olmalı" iken, öğretmenler \%19 ile veliler \%28.6 ile "Nitelikli okullar için sınav yapılmalı" ve "Adrese dayalı yerleştirme yapılmamalı" temalarında yoğunlaşmıştır. Öğretmen veliler ise \%25 ile ağırlıklı olarak "Sorular ders içeriği ile uyumlu olmalı" temasında yoğunlaşmıştır.

\section{Sonuç, Tartışma ve Öneriler}

Bu çalışmada, TEOG ve LGS sisteminin en çok kabul ve ret gören özellikleri öğrencilerin, öğretmenlerin, velilerin ve öğretmen velilerin görüşleri doğrultusunda incelenmiştir. Elde edilen sonuçlara göre "M16: Sınava giremeyen öğrenciler için mazeret sınavı yapılmalıdır" maddesinin öğrenci, öğretmen, veli ve öğretmen veliler için önemli maddelerden biri olduğu görülmektedir. Güler, Arslan ve Çelik (2019) tarafindan yapılan çalımada öğretmenler, tek sınav uygulamasının sınav sisteminin zayıf bir yönü olduğunu belirtirken, Şad ve Şahiner (2016) tarafından yapılan çalışmada, öğrenci, öğretmen ve veliler tarafından mazeret sınavının yapılması isabetli bir karar olarak vurgulanmıştır. Mazeret sınavının yapılması, sistemin süreç odaklı olmasına katkı sağlamaktadır. Ayrıca, yapılan görüşmeler sonucunda öğretmenler tarafindan, TEOG sisteminde uygulanan ancak LGS sisteminde uygulanmayacak olan mazeret sınavları yerine herkesin girebileceği iki merkezi sınavın yapılmasının ve daha yüksek puanın yerleştirmede tercih edilmesinin daha uygun olabileceği belirtilmiştir. Dolayısıyla tek bir sınav yerine birden fazla sınava girme hakkı tanınması öğrencileri rahatlatabilir.

"M14: Fen Lisesi gibi özel nitelik gerektiren okullara sınavla öğrenci alınmalıdır" maddesi öğretmen, veli ve öğretmen veliler tarafından önemli madde olarak görülmesine rağmen öğrenciler bu maddeyi önemli bir madde olarak görmemiştir. Yapılan görüşmeler sonucunda da benzer sonuçlar elde edilmiş ve nitelikli okullara sınavla öğrenci alınması gerektiği belirtilmiştir. Aydın (2008) tarafından yapılan çalışmada sınavla öğrenci seçmenin daha kararlı ve güvenilir olduğu ifade edilmiştir.

"M9: Yanlış yapılan sorular doğru soruları götürmemelidir" ve "M11: Öğrenciler sınava kendi okullarında girmelidir" maddeleri öğrenci ve veliler tarafından önemli birer madde olarak görülmektedir. Yapılan görüşmeler sonucunda da sınav sonuçlarındaki yanlış cevap sayısının doğru cevap sayısını etkilememesi gerektiği ve her sınıf düzeyin yılsonunda sınav yapılması gerektiği belirtilmiştir. Şad ve Şahiner (2016) tarafindan yapılan çalışmada da bu iki kriter öğrenci ve veliler açısından en fazla desteklenen kriterler arasında yerini almıştır.

"M19: Sınav sadece çoktan seçmeli sorulardan oluşmalıdır" maddesi öğrenci ve öğretmen veliler tarafindan önemli bir madde olarak görülmüştür. Öğrenciler ile yapılan görüşmeler sonucunda açık uçlu sorular yerine çoktan seçmeli sorular sorulması gerektiği belirtilmiştir. Öğretmenlerin ve öğretmen velilerin bir kısmı açık uçlu soruların cevabının kısa ve net olması nedeniyle amacına ulaşamadığını ve çoktan seçmeli soruların sorulması gerektiğini ifade etmiştir. Diğer taraftan, çoktan seçmeli soruların bilişsel açıdan bilgi basamağında kaldığını ve bu nedenle analiz ve sentez basamaklarında açık uçlu soruların sorulması gerektiğini belirten öğretmen ve öğretmen veliler de görülmüştür. Benzer şekilde, Özden, Akgün, Çinici, Sezer, Yıldız ve Taş (2014) tarafindan yapılan çalışmada çoktan seçmeli soruların geniş düşünme seviyesi olarak tanımlanan üst düzey bilişsel becerileri ölçmede yetersiz kaldığı belirtilmiştir. Ancak, çoktan seçmeli soruların tesadüfi hatalardan arınık olması ve daha adil değerlendirmeye imkân tanıması sebebiyle daha kullanışlı olduğu da 
söylenebilir. Ayrıca, yapılan görüşmeler sonucunda katılımcıların üzerinde durduğu diğer bir husus da sınav sistemlerinin eğitim programına uygun olarak hazırlanması gerektiğidir. Benzer şekide Güler ve diğerleri (2019) tarafından yapılan çalışmada da sınav soruları ile kazanımların uyumsuz olduğu belirtilmiş ve sınav sorularının kazanımlara oranlada daha üst bilişsel düzeyde kaldığı ifade edilmiştir. Sınavlarda açık uçlu sorular sorulması halinde analiz ve sentez basamağına çıkılabilmesi için orijinal yanıtlar vermeye olanak tanınarak sorular kısa yanıtlı olma durumundan çıkarılabilir. Bu bağlamda farklı soru tiplerinin kullanılması daha anlamlı olabilir.

Diğer taraftan, "M4: Ortaöğretim okulları kendi sınavını kendileri yapmalıdır" maddesi öğrenci, öğretmen, veli ve öğretmen veliler tarafından en uygun olmayan madde olarak görülmektedir. Çelik (2010) tarafından yapılan çalışmada, kurumlara kendi öğrencilerini seçme esnekliğinin tanınması gerektiği önerilse de bunun yapılan bir merkezi sınav sonucuna göre yapılması gerektiği belirtilmiştir. Öğrenciler ve öğretmenlerle yapılan görüşmeler sonucunda da sınavların MEB tarafindan merkezi olarak yapılması gerektiği vurgulanmıştır. "M1: Öğrenci adresine en yakın okula kayıt yaptırmalıdır" ve "M20: Ortaöğretime geçiş için yapılan sinav tek bir oturumda tamamlanmalıdır" maddeleri de öğrenci, öğretmen, veli ve öğretmen veliler tarafindan uygun olmayan maddeler olarak görülmüştür. Yapılan görüşmeler sonucunda adrese dayalı yerleştirmenin zengin ve fakir sınıf ayrımına neden olacağ1 için tercih edilmemesi gerektiği vurgulanmıştır. Ayrıca, "M2: Sınavda çoktan seçmeli sorularla birlikte açık uçlu sorulara da yer verilmelidir" maddesi de yine öğrenci, öğretmen veli ve öğretmen veliler tarafindan uygun olmayan maddelerden biri olmuştur.

"M21: Sınavda toplam 90 sorunun olması başarıyı ölçmek için yeterlidir" maddesi öğretmen ve öğretmen veliler tarafindan uygun olmayan maddelerden biri olarak görülmüştür. Yapılan görüşme sonucunda, 6 temel ders için hazırlanan toplam 90 soruluk bir sınav başarıyı ölçmek için yeterli görülmemiştir. Bir dersi ölçmek için soru sayısının 10 olması yetersiz görülmüş ve her dersin 20 sorudan oluşmasının yeterli olabilceği belirtilmiştir. Ayrıca, 155 dakikalık bir sınavın tek oturumda gerçekleşmesinin öğrenciler açısından yorucu olabileceği düşünülmüştür. Özkan, Güvendir ve Satıc1 (2016) tarafından yapılan çalışmada her ders için farklı zamanlarda sınava girmenin öğrencileri rahatlatacağı belirtilmiştir. Dolayısıyla yeni sınav sisteminde farklı derslerin sınavlarının farklı oturumlarda yapılmasınındaha uygun olacağı düşünülmektedir.

"M17: Din Kültürü ve Ahlak Bilgisi dersi için farklı dine mensup öğrenciler de düşünülerek daha genel sorular sorulmalıdır" maddesi öğretmenler tarafından kabul gören bir madde olmuştur. Ülkemizde isteğe bağlı din dersi uygulaması 1948 yılından itibaren başlamış ve 1982-1983 eğitim öğretim yılına kadar devam ve sınav mecburiyeti ile okutulmuştur (Doğan ve Tosun, 2002). 1982 Anayasası ile ilk ve orta öğretim kurumlarında din ve ahlak öğretimi zorunlu hale getirilmiş ve "Din Kültürü" daha önce okutulan "Ahlak Bilgisi" dersi ile birleştirilerek "Din Kültürü ve Ahlak Bilgisi" dersi uygulanmaya başlanmıştır. Yıldız (2009) tarafından yapılan çalışmada, küreselleşen dünyanın çok dinli ve çok kültürlü bir yaşamla tanıştı̆̆ ve inanılan dinin yanı sıra diğer dinlerin de öğretiminin zorunlu hale geldiği belirtilmiştir. Ayrıca, İslam dini dışındaki dinler hakkında bilgi edinmenin öğrencilerin inanç ve kültür dünyalarını zenginleştireceği, toplum ve dünya barışına katkı sağlayacağı düşünülmüsstür (Yıldız, 2009). Dolayısıyla sınav sorularında tek bir din üzerine yoğunlaşmak yerine farklı dinleri kapsayacak sorular sormak, sınav sisteminin evrenselliğine katkı sağlayacaktır.

Öğrenci, öğretmen, veli ve öğretmen veliler ile yapılan görüşme sonuçlarına göre, değişen sınav sistemlerinin aynı yıl yerine sonraki yıllarda kademeli olarak uygulanmaya başlaması gerektiği vurgulanmıştır. Sınav sorularının MEB tarafından hazırlanması gerektiği belirtilmiş, ancak sınavda görevli kişiler için farklı görüşler elde edilmiştir. Öğrenciler, TEOG sisteminde olduğu gibi öğretmenlerin sınavlarda görevli olması gerektiğini düşünürken, öğretmenler yapılan sınavlarda görev almamayı, öğretici ve eğitici olarak görevini yerine getirmeyi tercih etmiş̧tir. Bu çalışmada, TEOG ve LGS sistemlerinin her ikisinin de olumlu ve olumsuz yanlarının olduğu görülse de TEOG sistemine yönelik daha pozitif düşünceler beslendiği ve daha uygun bir sınav sistemi olarak görüldüğü belirlenmiştir. Yanlış yapılan soruların doğru soruları götürmemesi, öğrencilerin sınavlara kendi okularında girmesi, sınava giremeyen öğrenciler için mazeret sınavının yapılması TEOG sisteminin olumlu yanları olarak görülmüştür. Buna karşın, TEOG sisteminde sadece 8. sinıfta sınav yapılması, 
yapılan sinavların tamamı yerine sadece bir sınavın MEB tarafindan merkezi olarak yapılması ve soru dağılımının her ders için eşit olması olumsuz bir uygulama olarak belirtilmiştir. LGS sisteminde 6.7 . ve 8. sınıfların tamamına sınav uygulanması ve soru dağılımlarının dersin ağırlığına göre farklılık göstermesi olumlu yanlar olarak belirtilmiştir. Soru sayısının az olması, düzeltme formülünün uygulanması ve adrese dayalı yerleştirmenin esas alınması ise olumsuz yanlar olarak ifade edilmiştir. Açık uçlu soruların sorulması ise her iki sistemde de olumsuz olarak görülen bir diğer özellik olarak belirtilmiştir. Her iki sistemde de bulunan nitelikli okullara sınavla yerleştirmenin yapılması ve 6. 7 . ve 8. sınıf yılsonu başarı puanlarının değerlendirmeye alınması olumlu olarak görülen diğer önemli unsurlardır. Yılsonu başarı puanlarının dikkate alınması, yapılandırmacı yaklaşımı temel alan süreç temelli değerlendirmenin ön plana çıkmasına olanak tanıyabilir ve tespit edilen kriterler göz önünde bulundurularak yeni bir sinav sisteminin önerisi yapılabilir. 


\section{Kaynaklar}

Atılgan, H. (2018). Türkiye'de kademeler arası geçiş: dünü-bugünü ve bir model önerisi. Ege Eğitim Dergisi, 19(1), 1-18.

Aydın, S. (2008). Orta ve yükseköğretim kurumlarına öğrenci seçme sistemi: Bir öneri. Bilim, Eğitim ve Düşünce Dergisi, 8(2).

Aykaç, N., ve Atar, E. (2014). Geçmişten günümüze ilköğretimden ortaöğretime geçiş sisteminin değerlendirilmesi. A. Akdoğanbulut İnsan, ve A. Yavuz Akengin (Yay. haz.), Cumhuriyet'in Kuruluşundan Günümüze Eğitimde Kademeler Arası Geçiş ve Yeni Modeller Uluslararası Kongresi, 16-18 Ocak 2014, Antalya, Türkiye, Bildiriler içinde (s. 83-104). Antalya: Atatürk Araştırma Merkezi.

Çelik, R (2010). Üniversitelerde seçim sistemleri ve çözüm önerileri. Cumhuriyetimizin 100. Yllına Doğru Üniversite Vizyonumuz. 16-18 Nisan, Türk Eğitim Sen Ankara.

Doğan, R. ve Tosun, R. (2002). Din Kültürü ve Ahlak Bilgisi Öğretimi, Ankara: Pegem A yayınc1l1k

Elçi, Y., Süzme, P. S., Yıldız, R., Canbolat, Y., ve Çelik , O. (2016). Ortaögretim izleme ve değerlendirme raporu (Editör: Hacı Ali Okur). Ankara: Milli Eğitim Bakanlığı Ortaöğretim Genel Müdürlüğü.

ERG (2013). Yeni ortaögretime geçiş sistemi üzerine değerlendirmeler. İstanbul: Eğitim Reformu Girişimi.

Ergin, O.N. (1977). Türkiye maarif tarihi. İstanbul: Eser Kültür Yayınları.

Güler, M., Arslan, Z., ve Çelik D. (2019). 2018 Liselere Giriş Sınavına İlişkin Matematik Öğretmenlerinin Görüşleri. YYÜ Eğitim Fakültesi Dergisi. 16(1), 337-363.

Gür, B. S., Çelik, Z., ve Coşkun, İ. (2013). Türkiye'de ortaöğretimin geleceği: hiyerarşi mi, eşitlik mi? Ankara: SETA Analiz.

Güven, İ. (2010). Türk ĕgitim tarihi. Ankara: Naturel.

Howell, D.C. (2013). Statistical methods for psychology. Wadswort Cengage Learning: USA.

Kaplan, P. (2017, 17 Eylül). LGS, OKS, SBS, TEOG... Stradaki?. Erişim adresi: http://www.pervinkaplan.com/detay/lgs-oks-sbs-teog-siradaki/3685

Karasar, N. (2005). Bilimsel araştırma yöntemi. Ankara: Nobel Yayınları.

Küçüker, E. (2017). Türkiye'de kademeler arası geçiş ve öğrenci akışının gelişimi. Eğitim Bilimleri Fakültesi Dergisi, 50(1), 43-97.

MEB (1973, 24 Haziran). 1739 sayılı Milli Eğitim Temel Kanunu. Resmi Gazete (Sayı: 14574). Erişim adresi: http://www.mevzuat.gov.tr/MevzuatMetin/1.5.1739.pdf

MEB (1975, 1 Aralık). Milli Eğitim Bakanlığı'nın 01.12.1975 tarihli ve 11459 sayılı genelgesi, Ana Britannica Genel Kültür Ansiklopedisi, 2(15), 234-235

MEB (1990, 12 Aralık). Anadolu Öğretmen Liseleri Yönetmeliği. Resmi Gazete (Sayı: 20723). Erişim adresi: http://www.resmigazete.gov.tr/arsiv/20723.pdf

MEB (2013, 20 Eylül). Temel eğitimden ortaöğretime geçiş sistemi ile ilgili sıkça sorulan sorular. MEB._Erişim_adresi:_http://www.meb.gov.tr/duyurular/duyurular2013/bigb/tegitimdenoogreti megecis/MEB SSS $20 \quad 09$ 2013.pdf

MEB (2014, 5 Haziran). Anadolu öğretmen liseleri. MEB (Say1: 83203306/10.03/2288835) Erişim_adresi:_https://www.memurlar.net/common/news/documents/471293/10102753_ogretm en.pdf

MEB. (2016). Milli eğitim istatistikleri: Örgün eğitim 2016/'17. Ankara: Milli Eğitim Bakanlığı, Strateji Geliștirme Başkanlığı, Resmi İstatistik Programı.

Merriam, S. B. (2013). Nitel araştırma: Desen ve uygulama için bir rehber (3. Baskıdan Çeviri, Çeviri Editörü: S. Turan). Ankara: Nobel Yayın Dağıtım.

Miles, M. B. ve Huberman, A. M. (1994). Qualitative data analysis: An expanded sourcebook. New York: Sage

Özden, M., Akgün, A., Çinici, A., Sezer, B., Yıldız, S., ve Taş, M. M. (2014). Merkezi sistem ortak sınav fen bilimleri sorularının Webb'in bilgi derinliği seviyelerine göre analizi. Adıyaman University Journal of Science, 4(2), 91-108.

Özkan, G. (2017, 16 Eylül). LGS, OKS, SBS derken TEOG da bitiyor, son 13 yılda beşinci sistem geliyor. Hürriyet. Erişim adresi: http://www.hurriyet.com.tr/egitim/lgs-oks-sbs-derken-teog-dabitiyor-son-13-yilda-besinci-sistem-geliyor-40581137 
Özkan, Y. Ö., Güvendir, M. A., ve Satıcı, D. K. (2016). Temel eğitimden ortaöğretime geçiş (TEOG) sınavının uygulama koşullarına ilişkin öğrenci görüşleri. Eğitimde Kuram ve Uygulama, 12(6), $1160-1180$.

Patton, M. Q. (2005). Qualitative research. New York: John Wiley \& Sons, Ltd.

Salkind, N. J. (2010). Encyclopedia of research design. SAGE Publications: London

Szymanski, E. M., ve Linkowski, D. C. (1993). Human resource development: An examination of perceived training needs of certified rehabilitation counselors. Rehabilitation Counseling Bulletin, 37(2), 163- 176.

Srinivasan, S.; Ambedkar, V. (2015). Job satisfaction towards teaching profession among the higher secondary school teachers. IJAR, 1(3), 66-68.

Şad, S. N., ve Şahiner, Y. K. (2016). Temel eğitimden ortaöğretime geçiş (TEOG) sistemine ilişkin öğrenci, öğretmen ve veli görüşleri. Illköğretim Online, 15(1), 53-76.

Yıldırım, A., Şimşek, H. (2005). Sosyal bilimlerde nitel araştırma yöntemleri. Ankara: Seçkin Yayınları .

Yıldız, İ. (2009). Din Kültürü ve Ahlak Bilgisi dersi: Zorunlu mu kalmalı, yoksa seçmeli mi olmalı?. TÜBAV Bilim Dergisi, 2(2), 243-256.

Yılmaz, İ. (2017, 5 Kasım). Bakan Yllmaz, AA Editör Masası'nda ortaöğretime geçişte yeni uygulamayı açıkladı. MEB. Erişim adresi: http://meb.gov.tr/m/haber/14882/tr 


\section{Extended Abstract}

\section{Introduction}

In the Turkish education system, since 1955, it has been administered examination-based student placement system for the transition system to the secondary schools. The last of the system implemented in this way has been implemented in 2013-2014 academic year under the name of the transition from Basic Education to Secondary Education (TEOG) system. In the TEOG system of which main purpose is strengthening student, teacher and school relationship and spreading the success assessment to process, one of the written exams that students have already entered for each course instead of a new exam was applied centrally by Ministry of National Education. As of the academic year of 2017-2018, TEOG system was abolished and Free Registration System which is based on the address-based placement and optional was introduced. In this system, which is called the High School Entrance Exam (LGS), questions will be selected from the ministry's pool of questions instead of the central exam and examinations will be organized by the Provincial National Education Directorates. The exam will not be mandatory and will cover only the Science High Schools and some project schools. Five of these schools accept students with the examination, five schools are addressbased schools. The others are boarding schools. Registration priority criteria in the locality of placement were determined as the preference order of the student, the degree of closeness to his / her home and the degree of closeness to school. Within this system, although the test is mentioned, based on the address is based on placements. In this study, opinions of students, teachers and parents about this new system were taken and the properties that should be in the examination systems were examimed according to these opinions.

\section{Method}

In the study, quantitative and qualitative research approaches were used together, and the survey model of the quantitative research models and the case study model of the qualitative research models were used. In the seceltion of the related schools was used simple random sampling. In the selection of 8th grade students, teachers and parents were used purposive sampling method. The reseach was conducted total 415 individuals in various places in Turkey. Data were collected by using questionnaire method and analyzed by using content analysis and descriptive statistics. During the description process, the literature on TEOG and LGS systems was searched and item pool was created by taking expert opinions in the fields of curriculum and instruction, measurement and evaluation, and scale with 25 items was prepared. The scale prepared by using Google form was graded as "Disagree", "Undecided", "Agree" and administered to students, teachers and parents online. The data were analyzed using Microsoft Excel package program. The mean scores of each item for the parents, students, teachers and parents who are teachers were calculated and the priority items for the participants were determined.

\section{Findings}

In this study, the importance status of the items for the students, teachers and parents was examined and the items related to two or more groups of participants were determined. According to the results, "Make-up exams for students who cannot take the exam" item was identified as one of the important itemsfor students, teachers and parents. Although "Should be taken by exam to qualified schools such as Science High School" item was found as an important item, it is not important for students. " Incorrect answers should not invalidate correct answers" and "Students must take the exam in their school" items were seen as important items by students and parents. On the other hand, "High schools should do their own exam" item was determined as the worst option. "Student must register to the nearest school" and "High School Entrance Exam must be completed in one session" items were unsuitable items. "The exam should include open-ended questions together with multiple-choice questions" item were also determined to be one of the unsuitable item. 


\section{Conclusion, Discussion and Suggestions}

It was seen that make-up exam should be made, correct answers should not invalidate by incorrectly answered questions, students take the exam in their own schools were one of the most important items. In study conducted by Şad and Şahiner (2016) were emphasized that it was a good decision to make a make-up exam by students, teachers and parents. Should be taken by exam to qualified schools was among the important criteria. In a study on this subject, it was stated that choosing a student by making exam was more stable and reliable (Aydın, 2008). On the other hand, the examinations by schools was considered to be an unsuitable criterion for the students, teachers and parents. In the study by Çelik (2010), it has been suggested that the flexibility of choosing their students should be allowed, but this should be done according to a central exam result. Similarly, it was determined that enrolling students in the nearest school address and making exams in one session were unsuitable criterion. Moreover, one of the unsuitable items according to students, teachers, parents and parents who were teachers the exam included open-ended questions together with multiple choice questions. 


\section{EK-1}

Ortaöğretime Geçiş Sınav Sistemleri ile İlgili Maddeler

\begin{tabular}{ll}
\hline No & Maddeler \\
\hline $\mathbf{1}$ & Öğrenci adresine en yakın okula kayıt yaptırmalıdır \\
$\mathbf{2}$ & Sinavda çoktan seçmeli sorularla birlikte açık uçlu sorulara da yer verilmelidir. \\
$\mathbf{3}$ & Her dersin sınavı farklı oturumda yapılmalıdır. \\
$\mathbf{4}$ & Ortaöğretim okulları kendi sınavını kendileri yapmalıdır. \\
$\mathbf{5}$ & Ortaokul başarı ölçütleri ortaöğretim okullarına yerleştirmede hesap edilmelidir. \\
$\mathbf{6}$ & Sınavlar farklı günde yapılan iki oturum şeklinde olmalıdır. \\
$\mathbf{7}$ & Bazı liseler tarafından yapılan sınavlar bütün liseler için geçerli sayılmalıdır. \\
$\mathbf{8}$ & Sınav sorularının sayısı her ders için eşit olmalıdır. \\
$\mathbf{9}$ & Yanlış yapılan sorular doğru soruları götürmemelidir. \\
$\mathbf{1 0}$ & Daha objektif bir değerlendirme için yılda iki kez merkezi sınav yapılmalıdır. \\
$\mathbf{1 1}$ & Öğrenciler sınava kendi okullarında girmelidir. \\
$\mathbf{1 2}$ & Sinavda her ders için 20 soru sorulması yeterlidir. \\
$\mathbf{1 3}$ & Sosyal, sanatsal ve sporsal faaliyetler de değerlendirilmeye alınmalıdır. \\
$\mathbf{1 4}$ & Fen lisesi gibi özel nitelik gerektiren okullara sınavla öğrenci alınmalıdır. \\
$\mathbf{1 5}$ & Sinav süresinin 155 dakika olması öğrenciler için yorucu olur. \\
$\mathbf{1 6}$ & Sinava giremeyen öğrenciler için mazeret sınavı yapılmalıdır. \\
$\mathbf{1 7}$ & Din Kültürü ve Ahlak Bilgisi dersi için farklı dine mensup öğrenciler de düşünülerek daha genel \\
$\mathbf{1 8}$ & Sorular sorulmalıdır. \\
$\mathbf{1 9}$ & Ser iki yarıyılda ayrı ayrı sınav yapılmalıdır. \\
$\mathbf{2 0}$ & Ortaöğretime geçiş için yapılan sınav tek bir oturumda tamamlanmalıdır. \\
$\mathbf{2 1}$ & Sınavda toplam 90 sorunun olması başarıyı ölçmek için yeterlidir. \\
$\mathbf{2 2}$ & 6. 7. ve 8. Şınıf not ortalamaları değerlendirmeye alınmalıdır. \\
$\mathbf{2 3}$ & Her sorunun puanı eşit olmalıdır. \\
$\mathbf{2 4}$ & Öğrenciler bir oturumda en fazla 3 dersin sınavına girmelidir. \\
$\mathbf{2 5}$ & Sinav soruların dağılımı sınıf düzeylerine göre eşit sayıda olmalıdır. \\
\hline
\end{tabular}

